\title{
An Analysis of Proposed ESP Teaching Activities in Border Guard Automobile Transport Masters Training
}

\author{
Olha Lemeshko, Volodymyr Lemeshko, Nadiia Moroz, Ihor Bloshchynskyi* \\ Bohdan Khmelnytskyi National Academy of the State Border Guard Service of Ukraine, Ukraine
}

Received February 15, 2020; Revised March 30, 2020; Accepted April 19, 2020

Copyright $\odot 2020$ by authors, all rights reserved. Authors agree that this article remains permanently open access under the terms of the Creative Commons Attribution License 4.0 International License

\begin{abstract}
The article describes the teaching activities of English for specific purposes in future border guard Automobile Transport Masters training at the National Academy of the State Border Guard Service of Ukraine named after Bohdan Khmelnytskyi. The main attention is paid to developing of Working Curriculum anchored on the notion of "English for specific purposes" (ESP) for the educational program of the second (master's) level of higher education on specialty 274 "Automobile Transport". The purpose of this research is to study the ESP teaching activities in future border guard Automobile Transport Masters training. The methodology of the course is aimed at developing the border guards' professional communicative competency, which would facilitate their effective service in the border crossing points. The course program provides border guards with the opportunity to develop language competence to communicate with foreigners while conducting border surveillance activities and border checks. The structure of this educational program takes into account the elements of the PROJECT TUNING and the categories of BLOOM TAXONOMY. The classification of the types of teaching activities of ESP in future border guard Automobile Transport Masters training has been determined and substantiated. They include five components: warm ups, vocabulary, reading, listening, grammar and speaking with their corresponding activities. The results of its implementation are the number of officers in experimental group who had high and middle levels of English language proficiency increased by $25 \%$; and the number of officers in control group who had high and middle levels of English language proficiency increased by $6 \%$.
\end{abstract}

Keywords Border Guards, English Language Training, Master of Automobile Transport, English for Specific Purposes

\section{Introduction}

There are no ideal speakers or hearers of a language in everyday communication. It's impossible to master a language perfectly, and use it appropriately in all social interactions. It goes without saying that we may come across a great number of problems in the process of communication, and we tend to overcome the communication challenges by the use of communicative strategies (CS) required by the immediate context of language use. Linguists define $\mathrm{CS}$ in different ways: mutual attempts of two interlocutors to agree on a meaning in situations where requisite meaning strategies do not seem to be shared (Taron, 1980) [1]; the process of inter-lingual transfer and the context of learning as a learner tries to get a message through to a hearer or reader (Brown, 1994) [2]; potential conscious plans for solving what to an individual presents itself as a problem in reaching a particular communicative goal (Faerch and Kasper, 1983) [3]; strategy that a speaker used to solve the communication problems caused by the lack of appropriate forms in the mental lexical (Poulisse, 1989) [4]; and systematic attempt by the learner to express meaning by a target language in which the suitable systematic target language rules have not been formed (Cohen, 2004) [5]. Therefore, scholars in the field generally agree that the main purpose of $\mathrm{CS}$ is to deal with communication problems.

ESP language courses aim to address students' specialized needs and expectations relevant for their respective academic disciplines and professional domains (Hutchinson \& Waters, 1987) [6]. ESP courses, rather than general English courses, are then a good opportunity to introduce university level students to disciplinary language and communication in their respective areas. Nonetheless, today disciplinary language is more and more present beyond language-centered courses in university settings around the world (Woźniak, 2018) [7]. ESP courses can 
contribute to the development of students' communicative needs as well as generate enriching opportunities for interdisciplinary collaborative initiatives (Arnó-Macià \& Mancho-Barés, 2015) [8]. More integrated approaches can be more appropriate for the following years of studies when students have acquired more knowledge about their area of study and future profession (Woźniak, 2018) [7].

The analysis of literature on the theory and methods of foreign language training showed that the study of the problem of teaching professionally-oriented communication in a foreign language of different professions specialists was of great interest among researchers (Gordienko, 2015; Cohen, 2004) [9; 5]. Considerable attention is given to the study of second language acquisition (Ellis, 1994) [10]. A large number of works are devoted to the problems of formation and development of intercultural communicative competence in the field of professionally oriented learning a foreign language (Huang Jinqi, 2005) [11] as an important tool that considers culture in the selection of teaching approaches for adult (Linda, Z. Drumm, 2001) [12]. Such important factors as barriers and motivation, as well as interactive teaching strategies and technologies of practice-oriented approach in foreign languages teaching and learning were investigated by many scholars (Biryukova, Yakovleva, Kolesova, Lezhnina and Kuragina, 2015) [13].

The issues of creating foreign language environment in the English class by means of content-based warm-ups at its initial stage have been revealed in the research of (Karpushyna, Bloshchynskyi, Nakonechna, Skyba, 2019) [14]. Having analyzed the investigations on the issues under discussion, the role of the class starters and their contribution to the general second language teaching strategy and cadets' inducement to learn a foreign language in particular, have been defined.

However, the problems associated with the use of English by border guard (BG) officers while executing their service duties remain unresolved. That's why it is important to change traditional approaches in training of BGs. Taking into account the adoption of Standardized requirements of the $\mathrm{EU}$ to $\mathrm{BGs}$, there is a necessity to develop a new educational program in the specialty "Automobile Transport" to enhance the students' foreign communicative skills by development of working curriculum "ESP" through practical field training.

\subsection{The Aim}

The purpose of the article is to present ESP teaching activities in future border guard Automobile Transport Masters training at the National academy of the State Border Guard Service of Ukraine named after Bohdan Khmelnytskyi.

\section{Materials and Methods}

\subsection{Methods}

SBGS is being reformed in order to comply with the Schengen standards of European Union (EU). One of the Schengen requirements is staffing of the Ukrainian border crossing points $(\mathrm{BCP})$ with personnel that communicates effectively in English with foreign tourists, discuss trans-border cases with international colleagues, and participates at international training and professional conferences. Being aware of the importance of knowledge of English for BGs in conducting service duties the SBGSU tries to find ways for organizing English language training for its personnel. Therefore, the National Academy of the State Border Guard Service of Ukraine named after B. Khmelnytskyi (NASBGS) is contributing to this aim by providing officers' training in English through conducting discipline "ESP" to future border guard Automobile Transport Masters.

At the beginning of experiment, the initial assessment on the English language proficiency was conducted to determine the level of officers' English language knowledge, and at the end of experiment we made the final assessment in order to compare results. The CG was studied according to the current curriculum with traditional methods of training, and the EG was studied according to the improved curriculum. The suggested set of methods and professionally oriented themes were implemented in the educational process to teach officers the discipline "ESP" according to the educational program of the second (master's) level of higher education with amendments of 2019. At the end of studying for 18 hours, a complex field training was conducted. This allowed us to obtain statistical data to confirm our hypothesis about the practical significance of methods of teaching "ESP" by Automobile Transport Masters.

In this study, a mixed method approach was employed: theoretical - analysis, comparison, generalization, systematization of scientific works in order to find out the state of development of the research problem. Specification of essence, content and peculiarities of core points of the English language training of Masters who study according to the Working Curriculum "ESP" on "Automobile Transport" specialty was based on: empirical - testing, interviewing, discussion, observation of the pedagogical experiment. To analyze the results of the educational process, we used mathematical statistics.

\subsection{Participants}

The participants of this study were 324 officers (158 officers in control group (CG) and 166 of experimental group (EG) who were studying according to the educational program of the second (master's) level of higher education on specialty 274 "Automobile Transport" 
on the basis of the NASBGSU in 2018-2019.

\section{Results}

\subsection{Characteristics of the Educational Program of the Second (Master's) Level of Higher Education in Specialty 274 "Automobile Transport"}

According to the educational program of the second (master's) level of higher education in specialty 274 "Automobile Transport", NASBGSU provides training of BGs on professional qualification - qualifying as an officer of operational and tactical levels. The purpose of the educational program is to educate BGs in specialty "Automobile Transport", which provides employment in the SBGSU. The educational program has an applied orientation with a professional emphasis on the development of competencies necessary for solving the actual problems of ensuring the State border security at the operational and tactical levels. Teaching and training include problem-based and context training, activity and competency-oriented technologies, practical execution of combat training missions, practical in-service training and daily activities. The assessment is conducted at such forms of control: oral and written questioning, tests (including computer testing), results presentation of practical in-service training (practice), assessment of individual tasks, modular tests, credits, differentiated credits, examinations, certification (qualification work on defence). There are current controls and the final controls.

The structure of educational program includes: Integral competence, General competencies and Professional (specialized, subject) competencies. Nowadays competencies that make the base of professional activity are divided into two groups: general and professional (subject) competencies. These competencies were selected from the list of general competencies, determined by PROJECT TUNING (Tuning educational structures in Europe) [15], namely: ability to communicate in a foreign language with citizens of different nationalities; ability to develop the language of communication and communicative culture; ability to communicate with representatives of other professional groups; respect of diversity and multiculturalism; and ability to work in an international context. On the basis of educational program, we then developed the Working Curriculum "ESP" where the term of study is 1 year and 6 months based on the first (Bachelor's) level of higher education and including European Credits Transfer System. The goal of the program is development of foreign professional communicative competence that foresees the study of such aspects of language as speaking, reading, translation, auding and writing; development of dialogic and monologue skills in order to implement official duties during the State border protection; development of the knowledge and skills needed to become successful English users for simple communication for routine social and work requirements; development of general and professionally-oriented communicative language competencies in English to communicate effectively and confidently while performing service duties; demonstration of English proficiency in socially and culturally appropriate ways when interacting with international visitors and foreign counterparts; development of the skills for independent learning that will be used in the classroom and in future professional situations.

So far the program results of training are formulated more generally, so every program result is reached through the mastering of some educational components. The number of educational components or courses within the program is determined by the corresponding curriculum. Although this is a practical program, in its development, we incorporated Bloom's (1956) taxonomic elements to cover the program objectives and activities [16]. Therefore, upon completion of the discipline "ESP" the officers should be able to use: lexical material on topics that have been learnt, grammar material described in the curriculum, BG terminology, speech patterns for professional communication. The officers should also be able to communicate effectively in English while accomplishing service duties, and translate the texts in their specialty in order to make decisions in the service situations that might arise while performing their service duties which would require knowledge of the foreign language. Such situations may include a need to interview foreigners who violated the regulations of the State border crossing, and may also be expected to write a report on situation.

The content of the program includes courses with themes such as "State border protection", "Vehicles and their technical characteristics", "Law enforcement agencies of the world" and "Integrated Border Management". Foreign language studying is conducted as practical lessons under the guidance of the instructor as well as during self-preparation hours and self-guided work. The basis of training methods is a system-active approach and professionally-oriented education, differentiation of language activities on basic kinds of skills that focus on: oral speech, reading, translation, writing, auding, optimal balance, situational-role-play predetermination of educational activity, intensive complex use of technical equipment of training. For oral speech training we used different exercises, modelling of situations, from elementary speaking to solving of professionally oriented situations.

Each lesson started with a brief revision of the preceding lesson, then the instructor would state the objective for the day's lesson, and explain how the lesson fits into the course, and what would be the learning benefits to the students. The learning activities for the foreign language lesson, that is the English language incorporated role-playing in the 
communicative exercises to create real communication situations. This type of activity fits into a foreign language lesson and helps to develop real communication. When teaching new vocabulary, the activities given paid attention to tasks that enabled students to distinguish synonym ring of words and word-formation elements. During self-guided work, officers mastered and fixed lexical and grammatical material and automated speech skills, improved skills of oral speech. Forms of assessments include: oral questioning, writing questioning, testing, and examination. A successful course is one that meets the expectations of the military students whom it was developed for, and should also facilitate successful learning.

\subsection{Characteristics of the Working Curriculum "English for Specific Purposes"}

Taking into account the European Integration and training of border guards in the $\mathrm{EU}$, the educational program has been developed using the principles of the PROJECT TUNING and BLOOM TAXONOMY. The "ESP" is an obligatory course in the program since English is a Lingua Franca in this region. It consists of 3 European credits transfer system (90 educational hours). There are 2 modules, and each consists of 2 themes. The first module includes themes such as "State border protection", "Vehicles and their technical characteristics", and the second module - "Law enforcement agencies of world countries" and "Integrated border management". The duration of the program is 90 hours: 42 hours for practical lessons, 2 hours for test, 2 hours for examination, 22 hours - individual work, 18 hours - self-guided work, and 4 hours - exam. There are various lessons related to automobile transport at theme №2 "Vehicles and their technical characteristics": "Classification of vehicles", "Automobile construction", "All-wheeled drive vehicles", "Car body", "GAZ cars", "Internal combustion engines", "Transmission", "GAZ trucks", "Steering system and running gear", "UAZ vehicles", "Car electrical and electronic systems", "ZAZ cars", "Buses", "Ukrainian buses", "Motorcycles: functioning and classification", "Motorcycle construction", "Popular motorcycle models", "Snowmobiles", "All-Terrain vehicle", "Safety", "Cars of future", "Vehicle searches", "Vessel searches", "Aircraft searches", "Train searches".

The program does not only foreign language training exercises, such as filling in the gaps, multiple choice, crossword puzzles, rearranging, but it also includes tasks that require a certain amount of knowledge from officers' future activities that nurture capacity on: handling interviews, role-playing games and more. Using role-playing games in teaching some skills requires a special organization, so it is necessary to take into account the following methodological aspects: officers are convinced of the need to perform their "role" effectively; the division into groups and the distribution of roles taking into account the students' level of knowledge. To achieve such competencies through the role plays, we selected lexical material taking into account BGs' professional activities, and developed role-playing games in which officers were asked to play situations where they accomplished the roles of shift leaders at different types of BCP (highway, air, sea and railway). All these roles are familiar to officers, so it was possible to create a situation close to real communication.

\subsection{Example of Exercises of the Lesson "Conducting a Search"}

Conducted analyses showed that during the teaching of the course on "ESP" (Theme №2 "Vehicles and their technical characteristics"), the most effective and interesting lesson was "Conducting a search". This activity required that the methodology for conducting the search be revealed. The aim of this lesson is to equip students with the ability to give instructions to travelers (and crew members) during a vehicle search (aircraft, vessel, train) using appropriate vehicle terminology. Therefore, vocabulary learning is an essential part of any language learning process; hence, the attainment of and use of professionally specialized vocabulary is also one of the key concerns of ESP. Learners are expected to use specialized vocabulary for effective communication at professional activity. During the lesson all participants are expected to be fully involved in the learning process through practical exercises, brainstorming sessions, and working in small groups on specific tasks. A practical exercise is regarded as being essential for a better understanding of the topic. Usually the lesson starts with the most effective method known as a Warming up (or Brainstorming). The lesson activities that are given to the students are presented in the next section. Activities 1-10 provide an opportunity for students to learn and use technical vocabulary items required by the situation, and Activities $11-12$ enable students to practice the grammatical structures of English. Activities $13-14$ are designed to enhance and/or develop students speaking skills while Activities $15-17$ deal with reading comprehension. Listening Comprehension is practiced in activities $18-20$, and the Role Play tasks are presented in Activities $21-23$.

A: VOCABULARY LEARNING: Activity 1: Memory Game. Instructions: Work with a partner. You have 3 minutes to task (a) and (b). Task (a): Look at the picture for one minute. Task (b): Write down what you saw from the picture. Task (c): Share your ideas with the class. The group with the most information will be the winner (BCP, inspection group, technical devices, vehicle, passenger, hiding place).

Activity 2: What Do You Already Know? Instructions: Work with a partner and make a list of everything you know about vessels and searching of vessels. Think about the types of vessels, the parts, the process of searching, etc. 
You have 3 minutes. Share your lists with the class. Which pair has the most information? (desk housing, machine space, holder erection, conning room, hull, icebreaker, passenger carrier, cruise ship, ferry, cargo ship, tanker, container ship).

Activity 3: Information Exchange. Instructions: Get into 3 groups. Group 1 will make a list of the parts of a train. Group 2 will make a list of the types of trains. Group 3 will make a list of the places where people or objects can be hidden (sleeping compartment, cavity of a carriage, bunk, aisle, corridor, service compartment, toilet).

Activity 4: Car parts information exchange. Instructions: Your teacher will give you 2-3 names of parts of the car. If you do not know the word, look it up in a dictionary. Learn the name of it (pronunciation and spelling) and find it in the picture. Write it below the picture. Walk around the room and share the name of your car part with others. Find out the names of the other car parts and write them in the spaces given (usually we prepare 2-3 of the following words per strip of paper to give to each student: wheel well, glove box, fuel/gas tank, headrest, radiator, grill, window, seat).

Activity 5: Parts of a ship. Instructions: Work in pairs. Your teacher will show you a picture of a ship. Underline the things in the box that you can see. Use a dictionary to help you with new words such as (stern, engine compartment, anchor, crew, bow).

Activity 6: Adding on. Instructions: Look up the names of two more car parts you want to learn. Share your two new words with the class. Example: hood (American English) or bonnet (British English).

Activity 7: Sorting activity. Instructions: Look at the pictures. Use the correct words in the box and match them to a picture. Write the appropriate word under each picture (roof, sun roof, hood, grill, bumper, front fender, hub cap, window, tail light, trunk, door handle).

Activity 8: Which one is different? Why? Instructions: Read these lists of 4 things. Which one is different? Why? Circle the different thing. Example: arm rests, seats, mats, wheels. (Arm rests, seats, and mats are inside a car. Wheels are outside).

Activity 9: Matching. Instructions: Find a partner. Your teacher will give you words and definitions. Match each word to its definition. Check your answers with another pair (room for the propulsion unit, the left side of the ship, the front of the ship, a beam running from stern to bow).

Activity 10: Vocabulary. Instructions: Choose the correct definition for each word, such as crew (a group of people who work together, a place to store luggage and goods, to exit a plane).

In order to learn grammatical forms, we used such activities as: Listing. Instructions: Get into groups of 2-3 students. Make a list of DO's and DON'Ts for a BG who will search a vehicle. Present your ideas to the other groups. Vote on the best list (DO - tap each panel and listen carefully, DON'T - stop before checking under the hood).
B. PRACTICING GRAMMAR: Activity 11: Insert the propositions where necessary and translate them: Get your paper_passport control. Proceed the office, please. Your passport is not valid border crossing. Take your luggage you. I am master the ship. All papers are order. The smuggler put drugs the seat. The foreigners entered Ukraine. All passengers are requested to get the car.

Activity 12: Hide and seek. Instructions: Find a partner. One of you is A and one of you is B. Person A: Choose one of the following objects: a handgun, a case of vodka, a carton of cigarettes, 200 grams of hash, a homemade bomb, or something of your choice. Hide the object somewhere in your car and write down where you put it (but don't show your partner). Person B: You are a BG officer working at a BCP. You stop a car and you think the person has something illegal in his car. Try to find the object. Ask the person questions to find the object. When you have finished, change roles. (Teacher models the game with another student. S/he elicits questions such as "Is it in the ?" Is it under the ?". "Is it in the glove box? No, there's nothing here. Is it under the front seat? No, it's not. Is it under your spare tire? Yes, it is. What is it? It's a handgun." While students are playing the game, the instructor would circulate and write down any pronunciation or vocabulary mistakes. These would then be written on the board at the end of the game and students will be instructed to correct them.)

C: SPEAKING AND LISTENING SKILLS Activity 13: Strip story line-up. Instructions: You will be given a strip of paper with a sentence on it. Memorize your sentence. When you are finished, turn your paper over. At your teachers signal, stand up. Tell your sentence to your classmates. All of the sentences should make a conversation. Stand in line so that each sentence is in the correct order. When you are finished, check with your teacher (Excuse me, sir, but I need to check your vehicle; Could you please open the door and step out; Thank you. Now, please pop the hood; Okay. No problem. I have nothing to hide; Please, lift up the floor mat and open the glove box; All right, now please open the passenger door for me).

Activity 14: Picture description. Instructions: Look at the picture and describe the actions of the BGs in the groups: Say what you think is happening.

While reading such activities have been used: Instructions: Read the text and answer the questions: Are brakes important for car? Does the car usually have chassis? What is the body of car? What categories of wheels do you know?

D. READING COMPREHENSION ACTIVITIES: Activity 15: Comprehension. Instructions: Before you read the text, test your knowledge in lexical material and translate words: fuel tank, steering system, running gear, convers, crank mechanism.

Activity 16: True and False statements. Instructions: Decide whether the following statements are true or false 
(An engine is designed to convert energy into useful mechanical motion. The fuel tank stores and supplies fuel to the engine. Brakes are made of rubber, plastic and plasticine. Chassis consist of transmission). Instructions: Complete the sentences with appropriate words or phrases (An engine is a machine designed to ...; Automobiles are comprised of ...; Brakes are ...; What is your ...?; The passengers are not allowed to ...; Have you any ...?).

Activity 17: Fill in the gaps. Instructions: Insert the correct prepositions where it is necessary and translate the sentences (Will you get ... the bus. Who is the driver ... the van? Proceed ... the office, please).

E. LISTENING ACTIVITIES. Activity 18: Listening. Instructions: Listen to the conversation between a BG officer and a captain of a yacht. Discuss your answers with a partner.

Activity 19: Dual dictation. Instructions: Sit in pairs. Read your text to your partner. Do not show your paper to your partner! S/he should fill in the missing information. After you finish, your text will be complete. Compare your answers.

Activity 20: Class - Open pairs - Closed pairs (suitable for practicing short dialogues). Instructions: Class: After playing the recording repeat it line by line as a whole class. Open pairs: two officers act out the dialogue - either reading it aloud or reciting from memory. Closed pairs: whole the class practices the dialogue simultaneously.

The activities that are presented here have one common feature; that is, they are communicative tasks which are presented in the form of question-answer activities, and are aimed at the simultaneous participation of the entire group. In order to answer some of the questions students are expected to analyze the textual material and compare this information with their professional experience. At the end of the lesson, students use the learned material to resolve problems arising from typical situations in their professional activity. As a rule, there are different activities in each session, and these include activities such as: presentation, role play, interview, discussion.

After analyzing all kinds of activities, we worked out their classification according to didactic assignment. All types of activities were aimed at the enhancement of practical component of field training (Fig. 1).

After practicing general rules of conducting a search, we usually conduct the training at the simulation BCP "Podillia" at the territory of NASBSU. The duration for this training is 18 hours according to the schedule. Usually, we give students a task to conduct a professional activity at border patrol, such as: "Vehicle examination" solving such tasks as: to organize line of duty; to examine vehicles (vessels, trains, planes) traveling abroad and cargoes with the purpose to reveal offenders, hiding places and other places where weapons, drugs, ammunition and other illicit items prohibited for border crossing can be hidden; to identify stolen vehicles; to communicate with foreigners.

F. ROLE-PLAYS: Activity 21: Role-play "Train search". Instructions: Work in pairs. One of you is crew member on a goods train. The other person is a BG officer. Role-play a train search. When you finish, discuss what vocabulary, questions, and instructions you used. Make some notes about what you did. Share your notes with the class (What is the purpose of visit? All passengers are asked to take their seats and get papers ready for examination. Proceed to the service compartment).

Instructions: Work in pairs. Choose a different type of boat for your role-play on vessel checks (cruise ship, coastal fishing boat, freight carrier, ferry.) One of you plays the captain and the other plays the BG officer. Do your role-play. When you finish, prepare to do your role-play for your teacher. Choose several points that the officer will ask the captain. Make some notes, but do not write down your conversation. Role-play the situation for the teacher (to ride at anchor, stowaway, port of registry, port of destination).

Instructions: Work in pairs. One of you is a crew member of an aircraft. The other person is a BG officer checking the aircraft. When you finish role-playing, prepare to do the role-play for your teacher. Make some notes of what you'll say, but do not write the whole conversation. Role-play the situation for your teacher when you are ready (General Declaration, flight number, crew list).

Instructions: You will role-play a BG conducting a vehicle check with a traveler. Get into pairs and do your role-play. When you finish, plan to present your role-play to the class. Write down some words or phrases you will use, but do not write down the whole conversation. Present your role-play to the class. Listen to the role-plays while other groups are presenting. Write down the parts of the car you heard used. After each pair finishes, compare lists of words (bonnet, seat, trailer, plate number, driving permit).

Activity 22: Role-play. After the vehicle inspection Makarov gun with rounds (illegal migrant / smuggled goods) were detected, clear up the situation.

Activity 23: Role-play. After detailed vehicle inspection the forged number of VIN code (plate number / vehicle documents) was detected, clear up the situation. 


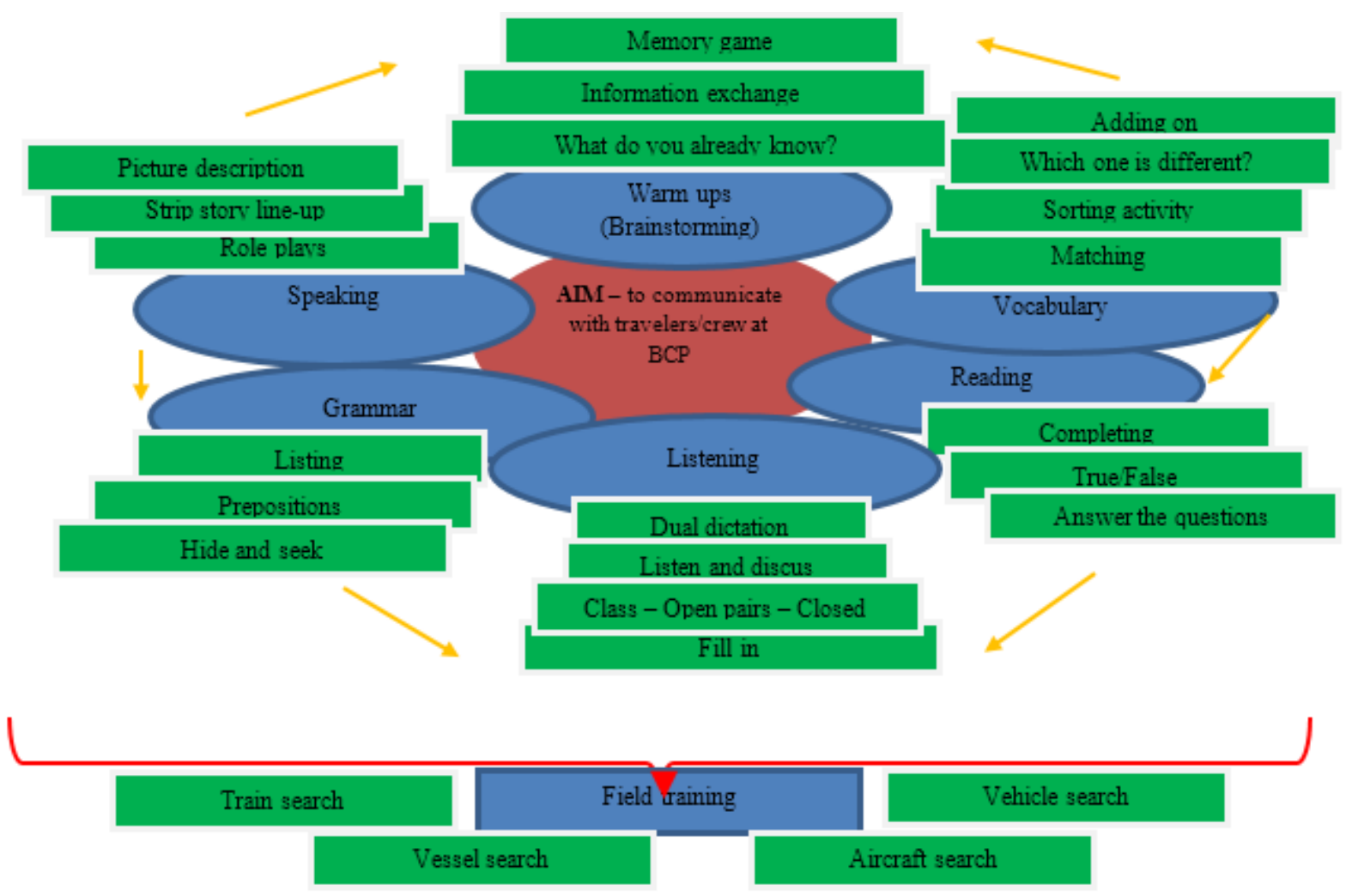

Figure 1. Classification of types of teaching activities of English for Specific Purposes in future border guard Automobile Transport Masters training

\subsection{Knowledge Assessment of Future Border Guard Automobile Transport Masters}

The final assessment (i.e. the exam) is conducted in order to test the level of knowledge and skills of professional foreign language communication based on the requirements of the English language curriculum at the NASBGSU. In this study, the result of the examination confirmed that the officers generally acquired a good level of texts reading and translation skills, knowledge of professional lexical material, military terminology, and ability to take decision according the current legislation in professional situations, such as in cases where the individual has to give instructions to travellers (crew members) during a vehicle search (aircraft, vessel, train) using appropriate vehicle terminology. The dynamics of knowledge quality of officers of control and experimental groups who were studying according to the Working Curriculum "ESP" allow stating the significant positive changes. The results also show that students who were studying following the Working Curriculum "ESP" with amendments (EG) had an opportunity to attain much better results than officers who did not have such an opportunity (control group). As a result, the performance in the examination conducted on July 2019, showed the following grades obtained by the students: Ten of EG students had the high level of English language proficiency, that is by $2 \%$ more than before the experiment; the middle level - 108 (by $23 \%$ higher), the low level - 48 (by $25 \%$ less than before the experiment); 16 of CG students had the high level, that was by $1 \%$ more than before the experiment, the middle level - 62 (by $5 \%$ higher), the low level - 80 (by $6 \%$ less) (see Table 1). The number of EG students who had high and middle levels of English language proficiency increased by $25 \%$ and the low level reduced by $25 \%$. Unlike EG, the number of CG students who had high and middle levels of English language proficiency increased by $6 \%$, and the low level reduced only by $6 \%$.

The comparison of EG officers' results of English language proficiency at the beginning and in the end of experiment confirmed the effectiveness of the Working Curriculum "ESP" based on the Kolmogorov-Smirnov criterion. The participants of the experiment both in the EGs and CGs had the same timetable of the English language classes. Due to the overall intensive training program, they had no opportunities to attend additional English courses of any kinds: individual tutoring, e-learning, computer-based multimedia, trainings, etc. So, we can state that all the officers had undergone training in equal conditions with the only difference of the curriculum used, and no other factors could have intervened during the experiment or have significant influence on the learning outcomes. 
Table 1. Dynamics of English language proficiency of Automobile Transport Masters before and after implementing the Working Curriculum "ESP”, $\mathrm{n}=324$

\begin{tabular}{|c|c|c|c|c|c|c|c|c|}
\hline \multirow{2}{*}{ Grades } & \multicolumn{3}{|c|}{ At the beginning of experiment } & \multicolumn{3}{c|}{ In the end of experiment } \\
\cline { 2 - 10 } & \multicolumn{2}{|c|}{ CG, $\mathrm{n}=158$} & \multicolumn{2}{c|}{ EG, $\mathrm{n}=166$} & \multicolumn{2}{c|}{ CG, $\mathrm{n}=158$} & \multicolumn{2}{c|}{ EG, $\mathrm{n}=166$} \\
\cline { 2 - 10 } & Persons & $\%$ & Persons & $\%$ & Persons & $\%$ & Persons & $\%$ \\
\hline High level & 14 & $9 \%$ & 6 & $4 \%$ & 16 & $10 \%$ & 10 & $6 \%$ \\
\hline Middle level & 56 & $35 \%$ & 70 & $42 \%$ & 62 & $40 \%$ & 108 & $65 \%$ \\
\hline Low level & 88 & $56 \%$ & 90 & $54 \%$ & 80 & $50 \%$ & 48 & $29 \%$ \\
\hline
\end{tabular}

\section{Conclusions}

Communicative skills in a foreign language have become an important agenda in the last few years because Ukraine attempts to be integrated into the EU. Nowadays traditional teaching methods of English studying are less active and do not enhance the process of BGs' education because they require much time. That is why it is important to focus not only on practical lessons, but also on self-guided work and extracurricular reading through the use of such learning methods as team learning, role play, practical development of listening and speaking skills, situation analysis, practical exercises, case studies, discussion and simulations which have proven to be more beneficial to the students. The results of the study also reveal that there is a need to develop English proficiency of SBGSU officials because the ability to communicate in English is one of the prior BGs' competences required to obtain in order to provide border control services at BCPs.

The educational program of the second (master's) level of higher education in specialty "Automobile Transport" has been developed to incorporate the framework for teaching ESP. The structure of educational program takes into account the PROJECT TUNING and employed the principles of BLOOM Taxonomy. The Working Curriculum "ESP" has been developed with 3 European Credits Transfer System (90 educational hours) and 2 modules with 4 themes ("State border protection", "Vehicles and their technical characteristics", "Law enforcement agencies of world countries" and "Integrated Border Management"). Taking these additions into account, we developed and characterized exercises of the lesson "Conducting a search". The classification of types of teaching activities of ESP to future border guard Automobile Transport Masters has been tested and proven to be successful strategies for teaching effective communication skills to students who use English as a foreign language in their professions. These activities include five components: warm ups, vocabulary, reading, listening, grammar and speaking skills.

Thus, the results of this study proved our hypothesis that it is effective to use ESP teaching activities when training future border guard Automobile Transport Masters in the National academy of the State Border Guard Service of
Ukraine named after Bohdan Khmelnytskyi during the lessons on ESP. As a result of the teaching activities used in studying the course "ESP" in the educational process of the NASBGSU, the number of EG officers who had high and middle levels of English language proficiency increased by $25 \%$. Therefore, the number of CG officers who had high and middle levels of English language proficiency increased by $6 \%$.

\section{REFERENCES}

[1] Taron, E. (1980). "Communication Strategies, Foreigner talk and repair in interlanguage?" Language learning, 30: 417-413.

[2] Brown, H. D. (1994). "Principle of Language Learning and Teaching”. 3rd ed. Englewood Cliffs: Prentice Hall.

[3] Faerch, C. and Kasper, G. (1983). "Plans and strategies in foreign language communication". Strategies in Interlanguage Communication. Harlow, UK: Longman.

[4] Poullisse, N. (1989). "The influence of task- and proficiency-related factors on the use of communication strategies: A quantitative analysis". Language learning. 30.

[5] Cohen, A. D. (2004). "Relevence Theory, Action Theory and Second Language Communication Strategies." Second Language Research, 20(3): 289-302.

[6] Hutchinson, T., \& Waters, A. (1987). "English for Specific Purposes: A Learning-Centred Approach." Cambridge: Cambridge University Press.

[7] Woźniak, M. (2017). "ESP in CLIL degree programmes". ESP Today - Journal of English for Specific Purposes at Tertiary Level, 5(2): 244-265.

[8] Arnó-Macià, E., \& Mancho-Barés, G. (2015). "The role of content and language in content and language integrated learning (CLIL) at university: Challenges and implications for ESP." English for specific purposes, 37: 63-73.

[9] Gordienko, E. A. (2015). "Formation of Readiness for Professionally-Oriented Foreign Language Communication of the Future Specialists of Customs at the University". Accessed: http://www.dslib.net/.

[10] Ellis, R. (1994). "The Study of Second Language Acquisition." Oxford: OUP. 
[11] Huang Jinqi (2005). "Developing intercultural strategic competence in oral English teaching school of foreign languages." Southwsat-china normal university press.

[12] Linda, Z. Drumm (2001). "Considering culture in the selection of teaching approaches for adult." Eric clearinghouse on adult. Career and vocational education.

[13] Biryukova, N., Yakovleva, S., Kolesova, T., Lezhnina, L. \& Kuragina, A. (2015). "Understanding Adult Learners as a Core Principle of Effective ESL-Educators." Review of European Studies, Vol. 7, 8: 147-155.

[14] Karpushyna, M., Bloshchynskyi, I., Nakonechna, A., Skyba, K. Creating Meaningful Foreign Language Environment by Means of Content-based Starters. Universal Journal of Educational Research 7.12 (2019) 2710 - 2716. doi: 10.13189/ujer.2019.071219.

[15] Tuning educational structures in Europe, TUNING. [Electronic resource]. Accessed: http://www.unideusto.org /tuningeu.

[16] Bloom, B. S. (1956). Taxonomy of educational objectives: The classification of educational goals: Handbook I, cognitive domain. New York: Longman. 